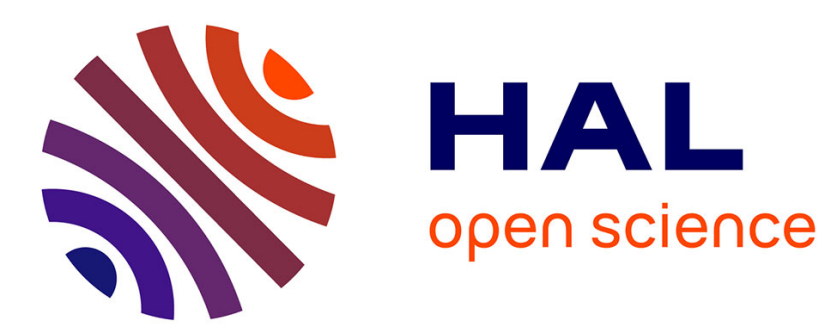

\title{
Synthesis and mechanical behavior of nanocomposite Mg-based bulk metallic glasses
}

Jean-Louis Soubeyroux, Sylvain Puech, Patricia Donnadieu, Jean-Jacques

Blandin

\section{- To cite this version:}

Jean-Louis Soubeyroux, Sylvain Puech, Patricia Donnadieu, Jean-Jacques Blandin. Synthesis and mechanical behavior of nanocomposite Mg-based bulk metallic glasses. Journal of Alloys and Compounds, 2007, 434-435, pp.84-87. 10.1016/j.jallcom.2006.08.297 . hal-00264760

\section{HAL Id: hal-00264760 \\ https://hal.science/hal-00264760}

Submitted on 18 Mar 2008

HAL is a multi-disciplinary open access archive for the deposit and dissemination of scientific research documents, whether they are published or not. The documents may come from teaching and research institutions in France or abroad, or from public or private research centers.
L'archive ouverte pluridisciplinaire HAL, est destinée au dépôt et à la diffusion de documents scientifiques de niveau recherche, publiés ou non, émanant des établissements d'enseignement et de recherche français ou étrangers, des laboratoires publics ou privés. 


\title{
Synthesis and mechanical behavior of nanocomposite Mg- based bulk metallic glasses
}

\author{
Jean-Louis Soubeyroux $^{* a}$, Sylvain Puech ${ }^{\mathrm{a}, \mathrm{b}}$, Patricia Donnadieu ${ }^{\mathrm{c}}$ and Jean-Jacques \\ Blandin ${ }^{\mathrm{b}}$ \\ a. Laboratoire de Cristallographie / CRETA, CNRS Grenoble, 25 avenue des Martyrs, BP166, 38402 Grenoble Cedex 9, France
}

b. Institut National Polytechnique de Grenoble (INPG), Génie Physique et Mécanique des Matériaux (GPM2)

UMR 5010, ENSPG, BP 46, 38402 Saint-Martin d'Hères Cedex, France

c. . Institut National Polytechnique de Grenoble (INPG),Laboratoire dethermodynamique et de Physico-Chimie Métallurgiques (LTPCM)

UMR 5614 , ENSEEG, BP 75, 38402 Saint-Martin d'Hères Cedex, France

\begin{abstract}
Nanocomposites can be produced by partial crystallization of bulk metallic glasses (BMG). The introduction of such nanocrystals in an amorphous matrix can sharply change the mechanical behavior of the glass at both room and high temperatures. In the present study, the effect of nanocrystallization in Mg-based BMG is studied in the system $\left(\mathrm{Mg}_{0.65} \mathrm{Cu}_{0.25} \mathrm{Gd}_{0.10}\right)_{100-\mathrm{x}} \mathrm{Fe}_{\mathrm{x}}$ for $0 \leq \mathrm{x} \leq 6$ and the effects of partial crystallization of the $\mathrm{Mg}_{65} \mathrm{Cu}_{25} \mathrm{Gd}_{10}$ BMG at various percentages of transformation. Various techniques (DSC, DRX, TEM) are used to get data about the nature, the volume fraction or the average size of the crystals. Mechanical properties at room temperature and nearby the glass transition are investigated in compression. The fracture stress is enhanced by iron addition, but no favourable effect of partial crystallization is observed for the $\mathrm{Mg}_{65} \mathrm{Cu}_{25} \mathrm{Gd}_{10}$ BMG. (c) 2001 Elsevier Science. All rights reserved

Bulk metallic glasses, Magnesium alloys, crystallization, $\mathrm{Mg}_{65} \mathrm{Cu}_{25} \mathrm{Gd}_{10}$.
\end{abstract}

\footnotetext{
${ }^{*}$ Corresponding author. Tel.: +33-476889039; fax: +33-476881280; e-mail: soubeyroux@grenoble.cnrs.fr.
} 


\section{Introduction}

Bulk metallic glasses (BMG) exhibit particularly attractive mechanical properties like high stresses to fracture and large elastic strains (up to $2 \%$ ). It is one of the reasons why they have been widely studied in the recent past. Among amorphous alloys, Mg-based BMG are of special interest since they can provide the possibility to obtain new light alloys for structural applications. Important efforts have been devoted to develop such Mg-bulk metallic glasses. Most alloys were focused on $\mathrm{Mg}-\mathrm{Cu}-\mathrm{Y}$ composition with various complementary element additions like Al, Pd, Ag, Ni or Zn [1-8]. More recently, glasses based on $\mathrm{Mg}-\mathrm{Cu}-\mathrm{Gd}$ compositions have been elaborated and tested [9-11] and present higher glass forming ability (GFA). Another interesting feature of BMG is the ability to nucleate by heat treatments, nanocrystals inside the structure, and thus to produce nanocomposites corresponding to nanocrystals embedded in an amorphous matrix. Despite some recent works on the Zr-based BMG, the mechanical properties of such nanocomposites remain quite poorly documented. It seems that partial crystallization may increase or decrease the mechanical properties of the BMG, depending on the volume fraction of the crystals, their composition, their size, their nature or their spatial distribution through the matrix [12-16]. No work was presented on the Mg-based alloys. Composite materials between MgCuNiZnAgY and Fe have been proposed by [17] leading in an increase in mechanical properties.In the present investigation, a $\mathrm{Mg}_{65} \mathrm{Cu}_{25} \mathrm{Gd}_{10}$ alloy was elaborated. The effects of partial crystallization on the mechanical properties of the composite glass / crystal were investigated. The effects of a composite material between $\mathrm{Mg}_{65} \mathrm{Cu}_{25} \mathrm{Gd}_{10}$ and $\mathrm{Fe}(\mathrm{x}=3$ and $6 \%)$ were also investigated.

\section{Experimental}

Elements with purity better than $99.9 \%$ were used as starting materials. $\mathrm{Cu}-\mathrm{Gd}$ or $\mathrm{Cu}-\mathrm{Gd}-\mathrm{Fe}$ as intermediate alloys were melted prior to be remelted with $\mathrm{Mg}$ to obtain the master alloy. The glasses of composition $\mathrm{Mg}_{65} \mathrm{Cu}_{25} \mathrm{Gd}_{10}$ and $\left(\mathrm{Mg}_{0.65} \mathrm{Cu}_{0.25} \mathrm{Gd}_{0.10}\right)_{97} \mathrm{Fe}_{\mathrm{x}}$ ( $\mathrm{x}=3$ and 6) were prepared by copper mould casting as cylinders of 4 or $6 \mathrm{~mm}$.

The degree of amorphicity was characterized by X-ray diffraction (XRD) analyses. The thermal glass stability was determined by differential scanning calorimetry (Perkin Elmer DSC 7 and Netzsch DSC 404S). Various heating rates were used. Except when it is mentioned in the text, most of the analyses were carried out with an heating rate of $10 \mathrm{~K} / \mathrm{min}$. After each run, a second run was performed in order to estimate the baseline. From DSC analyses, the characteristic temperatures $T_{g}$ (glass transition temperature) and $T_{x}$ (onset of crystallization) were measured. Isothermal treatments between $T_{g}$ and $T_{x}$ were carried out for various times (heating rates of about $200 \mathrm{~K} / \mathrm{min}$ ). In partially crystallized BMG, the volume fraction of transformed matter $\mathrm{F}_{\mathrm{T}}$ associated to a peak in DSC analysis is frequently deduced from 
the ratio $\mathrm{H}(\mathrm{t}) / \mathrm{H}_{\text {total }}$ where $\mathrm{H}(\mathrm{t})$ is the released heat flux at time $\mathrm{t}$ and $\mathrm{H}_{\text {total }}$ for the complete transformation. This procedure has been also applied in the case of Mg-based BMG [8]. The microstructures of the alloy were characterized by SEM-FEG and TEM observations.

The mechanical properties were investigated at room temperature by compressive tests. Compression rods were $4 \mathrm{~mm}$ in diameter and $6 \mathrm{~mm}$ in length, and great care was taken in surface parallelism and aspect. Compression was carried out with an initial strain rate equal to $5 \times 10^{-4} \mathrm{~s}^{-1}$ with WC platens and samples were conducted to failure. For crystallization experiments before compression tests, the samples were annealed at $438 \mathrm{~K}$ in oil bath, and the duration of heat treatment was deduced from isothermal DSC curves at the same temperature.

\section{Results}

\section{Thermal stability}

Fig. 1 displays XRD patterns taken from the cross-section of the rod confirming the amorphous structure of the as-cast alloys whereas Fig. 2 shows the corresponding DSC curves in continuous heating conditions. A glass transition temperature $\mathrm{T}_{\mathrm{g}}=417 \mathrm{~K}\left(144^{\circ} \mathrm{C}\right)$ is measured followed by a single crystallization peak with an onset crystallization temperature $T_{x}$ equal to $472 \mathrm{~K}\left(199^{\circ} \mathrm{C}\right)$. These values are in relatively good agreement with those reported recently for a similar composition [11]. It confirms also that Gd containing Mg BMG exhibit larger $\Delta \mathrm{T}$ than $\mathrm{Mg}_{60} \mathrm{Cu}_{30} \mathrm{Y}_{10}$ [8]. $\mathrm{T}_{\mathrm{rg}}=\mathrm{T}_{\mathrm{g}} / \mathrm{T}_{\mathrm{L}}=0.596$ and $\gamma=$ $\mathrm{T}_{\mathrm{x}} /\left(\mathrm{T}_{\mathrm{g}}+\mathrm{T}_{\mathrm{L}}\right)=0.422$.

The effect of substitution of yttrium by gadolinium in $\mathrm{Mg}_{65} \mathrm{Cu}_{25} \mathrm{X}_{10}$ has been investigated in [10], confirming that rods with larger diameters could be produced when gadolinium is used. The same value of $\operatorname{Trg}$ was reported for both alloys $(\approx 0.54)$ suggesting that $\operatorname{Trg}$ is probably not a pertinent parameter for comparing the glass forming abilities of the two compositions. Since the two alloys are very similar in terms of chemistry (negative heat of mixing in the liquid, atom size, etc), the authors suggested that the difference in GFA may be related to differences in electronic configuration between $\mathrm{Y}\left(4 \mathrm{~d}^{1} 5 \mathrm{~s}^{2}\right)$ and $\mathrm{Gd}$ $\left(4 \mathrm{f}^{7} 5 \mathrm{~d}^{1} 6 \mathrm{~s}^{2}\right)$ resulting in some changes in the short range order in the under cooled liquid.

The effect of the alloying of $\mathrm{Mg}_{65} \mathrm{Cu}_{25} \mathrm{Gd}_{10}$ with iron does not change the amorphous nature of the matrix as DSC events appear in the composite compound at exactly the same temperatures. In the diffraction pattern, iron peaks appear above the weavy diffraction characteristic of the BMG.

Crystallization kinetics were investigated at different temperatures in the glass regime. Fig. 3 shows an isothermal DSC curve registered at $423 \mathrm{~K}$ with the calculated volume fraction of transformed matter $\mathrm{F}_{\mathrm{T}}$. The vertical marks are the points where the samples have been prepared to do the mechanical compression tests.

\section{Mechanical properties}

Fig. 4 shows the results of compression tests performed on amorphous and partially crystallized samples 
annealed at $438 \mathrm{~K}$ for different values of crystallization. No signs of macroscopic plastic strain before failure are noticed. The dispersion of the results supports the idea of very brittle failure on these glasses. In the amorphous state, the fracture stress is about $650 \mathrm{MPa}$ with an elastic strain of 0.014. Upon crystallization, the fracture stress decreases continuously and falls to $335 \mathrm{MPa}$ for the fully transformed state. The Young's modulus stays close to the initial value of $45 \mathrm{Gpa}$. No increase of fracture stress is observed as pointed out in Zr-Based BMG [14] where the fracture stress increases up to a maximum then decreases.

Fig. 5 shows the results of compression tests performed on amorphous and $\left(\mathrm{Mg}_{0.65} \mathrm{Cu}_{0.25} \mathrm{Gd}_{0.10}\right)_{97} \mathrm{Fe}_{\mathrm{x}} \mathrm{BMG}$ samples. In the amorphous state, the fracture stress is about $650 \mathrm{MPa}$ with an elastic strain $(\varepsilon)$ of 0.014 , whereas it is $820 \mathrm{Mpa}$ with an elastic strain of 0.02 . These results are comparable with those obtained by $\mathrm{H}$. Ma[17], where the addition of $9 \%$ of iron leads to an increase of the fracture stress up to $990 \mathrm{Mpa}$ and $(\varepsilon) \sim 0.10$ in $\mathrm{Mg}_{65} \mathrm{Cu}_{25} \mathrm{Y}_{10}$ BMG.

\section{Discussion}

Amorphous state

It was possible to elaborate Mg-based BMG with a $6 \mathrm{~mm}$ diameter. Glass forming ability is known to be favored by multi component systems with compositions close to deep eutectic ones (to maintain the liquid state at temperatures as low as possible), large differences in atomic sizes (to increase the atomic packing density in the liquid and consequently to hinder diffusion processes) and negative heats of mixing between the solutes (to favor solute mixing in the liquid). These criteria are well satisfied in the case of the $\mathrm{Mg}_{65} \mathrm{Cu}_{25} \mathrm{Gd}_{10}$ alloy since the atomic radii are respectively $0.160,0.128$ and $0.178 \mathrm{~nm}$ for $\mathrm{Mg}, \mathrm{Cu}$ and $\mathrm{Gd}$ and the heat of mixing are $-3 \mathrm{~kJ} / \mathrm{mol},-6 \mathrm{~kJ} / \mathrm{mol}$ and $-22 \mathrm{~kJ} / \mathrm{mol}$ for Mg-Cu, Mg-Gd and Cu-Gd [20]. However these BMG display no plasticity, it's why we have tried two methods to enhance plasticity, to produce a composite with iron, to nucleate nanocrystals in the amorphous matrix.

Crystallization mechanisms in $\mathrm{Mg}_{65} \mathrm{Cu}_{25} \mathrm{Gd}_{10}$

In the case of $\mathrm{Mg}-\mathrm{Cu}-\mathrm{Y} \mathrm{BMG}$, it is generally assumed that only one kind of crystal $\left(\mathrm{Mg}_{2} \mathrm{Cu}\right)$ nucleates

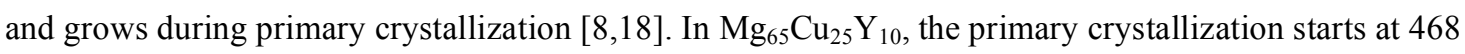
$\mathrm{K}(0.33 \mathrm{~K} / \mathrm{s})$ showing a mixture of $\mathrm{Mg}_{2} \mathrm{Cu}$ and super cooled liquid matrix [18]. In the case of $\mathrm{Mg}_{60} \mathrm{Cu}_{30} \mathrm{Y}_{10}$ [5] two distinct peaks were identified after the glass transition, the first peak arising mainly from the formation of $\mathrm{Mg}_{2} \mathrm{Cu}$ whereas during the second peak, other phases $\left(\mathrm{MgY}\right.$ and $\left.\mathrm{Cu}_{2} \mathrm{Y}\right)$ form. From the DSC curves, a single exothermic peak is reported for $\mathrm{Mg}_{65} \mathrm{Cu}_{25} \mathrm{Gd}_{10}(20 \mathrm{~K} / \mathrm{min})$.

In fact, on our TEM observations (Fig. 6.), there are already two populations observed on the annealed sample at $438 \mathrm{~K}$ with a crystallized fraction of $20 \%$. In the studied $\mathrm{Mg}-\mathrm{Cu}-\mathrm{Gd}$, the presence of $\mathrm{Mg}_{2} \mathrm{Cu}$ is confirmed, thanks to XRD and TEM observations. These crystals admit a quite rounded shape and their 
size reach quickly about $100 \mathrm{~nm}$ with relatively low growth kinetics during further annealing at $438 \mathrm{~K}$. However, another type of crystals can be also detected by these two techniques: $\mathrm{Cu}_{2} \mathrm{Gd}$. They are rod shaped. Similarly to what is observed in the case of $\mathrm{Mg}_{2} \mathrm{Cu}$ crystals, they grow quickly to a length of about $200 \mathrm{~nm}$ and diameter of about $50 \mathrm{~nm}$ in the first steps of crystallization and then keep a size relatively constant. In the present glass, DSC detects a single exothermic peak.

\section{Mechanical properties. Effect of partial crystallization on mechanical behavior}

We don't observe any increase of the fracture stress with the crystalline fraction as observed in Zr-based [14], or La-based [20] BMG. In $\mathrm{Mg}_{65} \mathrm{Cu}_{25} \mathrm{Gd}_{10}$, we observe only a decreasing value of the fracture stress with increasing crystallization fraction. The specificity of the Mg-based BMG could be related to the crystallization mechanism, since we observe two different populations of crystals with rather big sizes $(200 \mathrm{~nm})$ compared to the nanocrystals $(10 \mathrm{~nm})$ observed in the above mentioned glasses.

The question of crystal nucleation is not clear since some authors claim that some local ordering is present in the as-cast alloy or after relaxation at room temperature [11].

\section{Composite state}

The composite state is well represented in fig. 7. Iron forms dendrites of some micrometers in the amorphous matrix. XRD and DSC show clearly that the amorphous matrix in the composite and in the glass have the same properties. Fracture stress is really enhanced and slight plasticity appears. The $6 \%$ iron composite does not present better properties than the 3\% at the contrary of the study on $\mathrm{Mg}-\mathrm{Cu}-\mathrm{Y}$ where the plasticity increases with the iron addition of 9 or $13 \%$.

More investigations will be done on these alloys, particularly the fracture mechanisms will be studied in details.

\section{References}

[1] W. Liu, W.L. Johnson, J. Mater. Res., 11 (1996) 2388.

[2] K. Amiya, A. Inoue, Mater. Trans. JIM, 41 (2000) 1460.

[3] S. Linderoth, N.H. Pryds, M. Ohnuma, A.S. Pedersen, M. Eldrup, N. Nishiyama, A. Inoue, Mat. Sci. Eng. A304-306 (2001) 656

[4] H. Ma, E. Ma, J. Xu, J. Mater. Res., 18 (2003) 2288.

[5] Z. Kovacs, A. Castellero, A.L. Greer, J. Lendvai, M. Baricco, Mater. Sc. Eng., A387-389 (2004) 1012.

[6] S.V. Madge, A.L. Greer, Mater. Sc. Eng., A375-377 (2004), 759.

[7] N. Pryds, Mater. Sc. Eng., A375-377 (2004) 186.

[8] U. Wolff, N. Pryds, J.A. Wert, Scripta Mater., 50 (2004) 1385.

[9] H. Men, D.H. Kim, J. Mater. Res., 18 (2003) 1502. 
[10] H. Men, W.T. Kim, D.H. Kim, Mater. Trans. JIM, 44 (2003) 2141.

[11] G. Yuan, A. Inoue, J. All. Comp., 37 (2005) 134.

[12] Z.F. Zhang, G. He, J. Eckert, L. Schultz, Phys. Rev. Lett., 91 (2003) 045505.

[13] H.S. Kim, Scripta Mater., 48 (2003) 43.

[14] L.Q. Xing, C. Bertrand, J-P Dallas, M. Cornet, Mater. Sc. Eng., A241 (1998) 216

[15] Z. Bian, G.L. Chen, G. He, X.D. Hui, Mater. Sc. Eng., A316 (2001) 135.

[16] U. Wolff, N. Pryds, E. Johnson, J.A. Wert, Acta Mater., 52 (2004) 1989.

[17] H. Ma, J. Xu, E. Ma, Appl. Phys. Lett., 83 (2003) 2793

[18] R. Busch, W. Liu, W.L. Johnson, J. Appl. Phys., 83 (1998) 4134.

[19] H. Men, W.T. Kim, D.H. Kim, J. Non Cryst. Solids, 33 (2004) 29.

[20] J. Basu, N. Nagendra, Y. Li, U. Ramamurty, Phil. Mag., 83, 15 (2003) 1747.

[21] A.Takeuchi, A. Inoue, Materials Trans., JIM, 46, (2005) 2817 


\section{Figure captions}

Fig. 1. XRD patterns of $\mathrm{Mg}_{65} \mathrm{Cu}_{25} \mathrm{Gd}_{10}$ and $\left(\mathrm{Mg}_{0.65} \mathrm{Cu}_{0.25} \mathrm{Gd}_{0.10}\right)_{97} \mathrm{Fe}_{\mathrm{x}} \mathrm{BMG}$ as-cast $6 \mathrm{~mm}$ cylinders.

Fig. 2. DSC curves of $\mathrm{Mg}_{65} \mathrm{Cu}_{25} \mathrm{Gd}_{10}$ and $\left(\mathrm{Mg}_{0.65} \mathrm{Cu}_{0.25} \mathrm{Gd}_{0.10}\right)_{97} \mathrm{Fe}_{\mathrm{x}} \mathrm{BMG}$ as-cast $6 \mathrm{~mm}$ cylinders.

Fig. 3. Isothermal DSC curves of the $\mathrm{Mg}_{65} \mathrm{Cu}_{25} \mathrm{Gd}_{10} \mathrm{BMG}$ at $438 \mathrm{~K}$.

Fig. 4. Compression tests performed on $\mathrm{Mg}_{65} \mathrm{Cu}_{25} \mathrm{Gd}_{10} \mathrm{BMG}$.

Fig. 5. Compression tests performed on $\left(\mathrm{Mg}_{0.65} \mathrm{Cu}_{0.25} \mathrm{Gd}_{0.10}\right)_{97} \mathrm{Fe}_{\mathrm{x}}$ BMG.

Fig 6. TEM images of the $\mathrm{Mg}_{65} \mathrm{Cu}_{25} \mathrm{Gd}_{10}$ BMG annealed at $438 \mathrm{~K}$ with $20 \%$ of crystallization. a)TEM image,b) and c) are respectively electron diffraction patterns of the different circled areas.

Fig 7. SEM image of the $\left(\mathrm{Mg}_{0.65} \mathrm{Cu}_{0.25} \mathrm{Gd}_{0.10}\right)_{97} \mathrm{Fe}_{\mathrm{x}}$ BMG. 


\section{Figure captions}

Fig. 1. XRD patterns of $\mathrm{Mg}_{65} \mathrm{Cu}_{25} \mathrm{Gd}_{10}$ and $\left(\mathrm{Mg}_{0.65} \mathrm{Cu}_{0.25} \mathrm{Gd}_{0.10}\right)_{97} \mathrm{Fe}_{\mathrm{x}} \mathrm{BMG}$ casted as $6 \mathrm{~mm}$ cylinders.

Fig. 2. DSC curves of $\mathrm{Mg}_{65} \mathrm{Cu}_{25} \mathrm{Gd}_{10}$ and $\left(\mathrm{Mg}_{0.65} \mathrm{Cu}_{0.25} \mathrm{Gd}_{0.10}\right)_{97} \mathrm{Fe}_{\mathrm{x}}$ BMG casted as $6 \mathrm{~mm}$ cylinders.

Fig. 3. Isothermal DSC curves of the $\mathrm{Mg}_{65} \mathrm{Cu}_{25} \mathrm{Gd}_{10} \mathrm{BMG}$ at $438 \mathrm{~K}$.

Fig. 4. Compression tests performed on $\mathrm{Mg}_{65} \mathrm{Cu}_{25} \mathrm{Gd}_{10}$ BMG.

Fig. 5. Compression tests performed on $\left(\mathrm{Mg}_{0.65} \mathrm{Cu}_{0.25} \mathrm{Gd}_{0.10}\right)_{97} \mathrm{Fe}_{\mathrm{x}}$ BMG.

Fig 6. SEM images of the $\mathrm{Mg}_{65} \mathrm{Cu}_{25} \mathrm{Gd}_{10}$ BMG annealed at $438 \mathrm{~K}$ with $20 \%$ of crystallization.

Fig 7. SEM image of the $\left(\mathrm{Mg}_{0.65} \mathrm{Cu}_{0.25} \mathrm{Gd}_{0.10}\right)_{97} \mathrm{Fe}_{\mathrm{x}}$ BMG. 


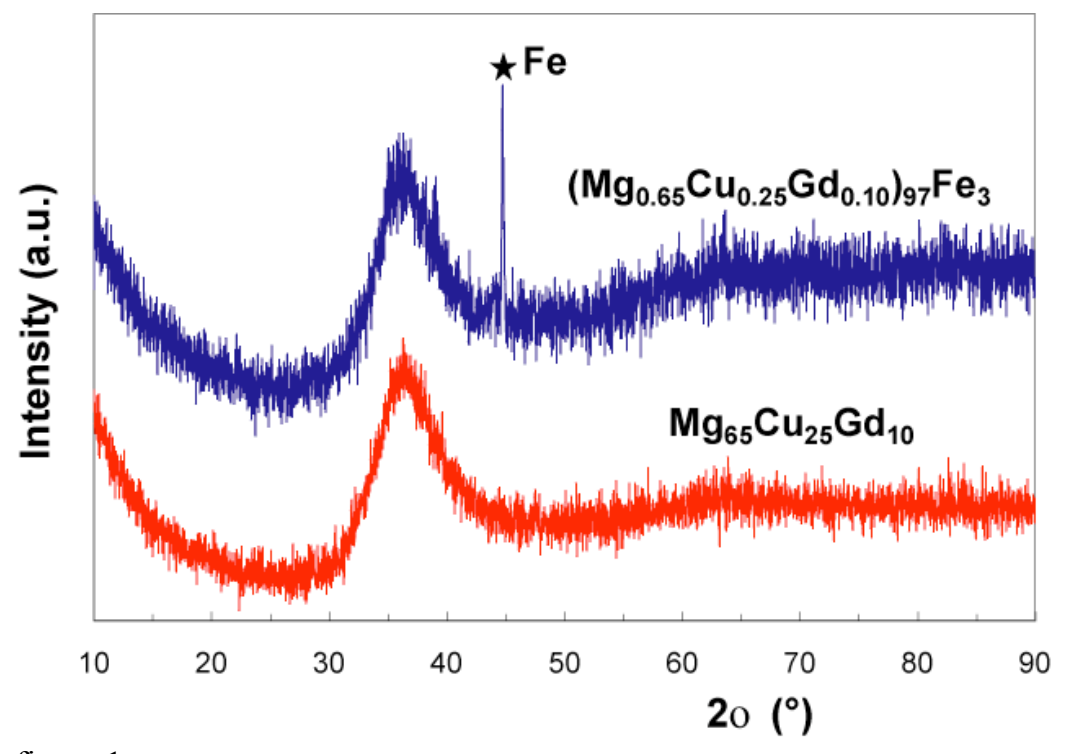

figure 1 


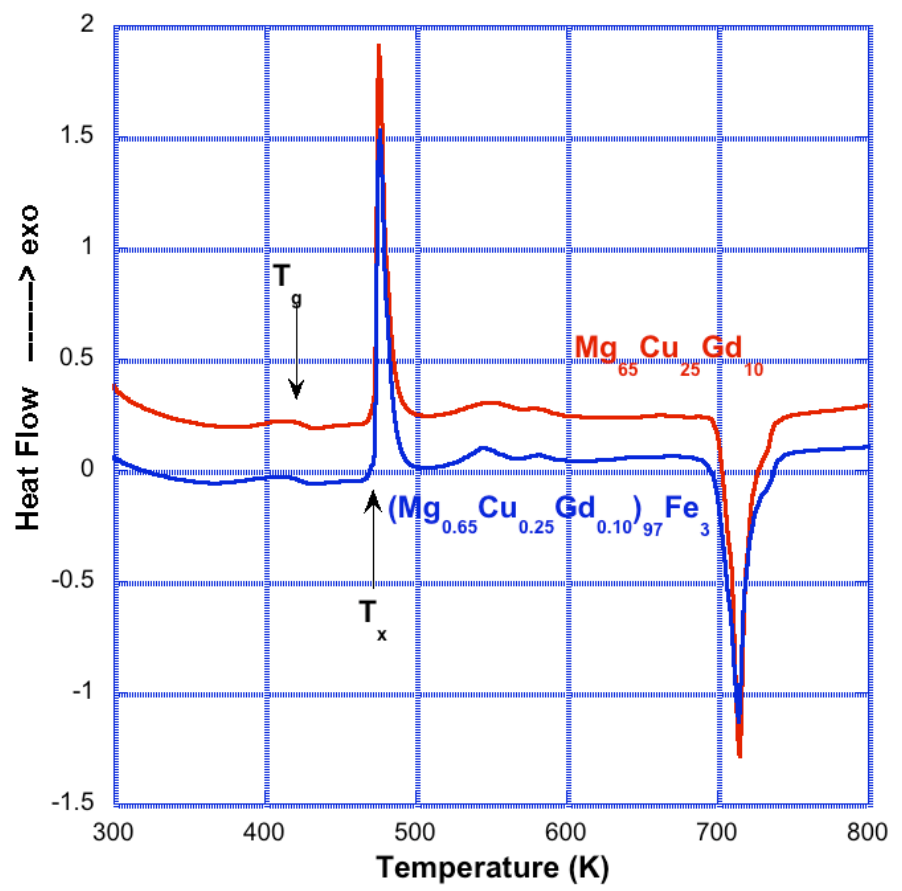

figure 2 


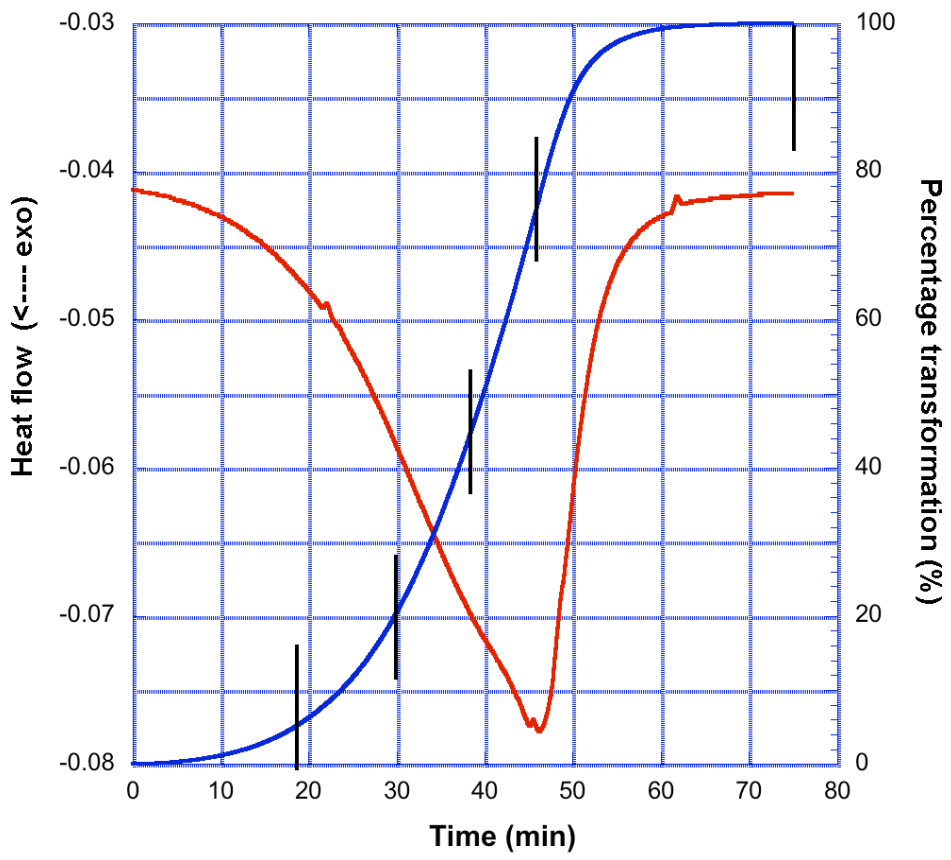

figure 3 


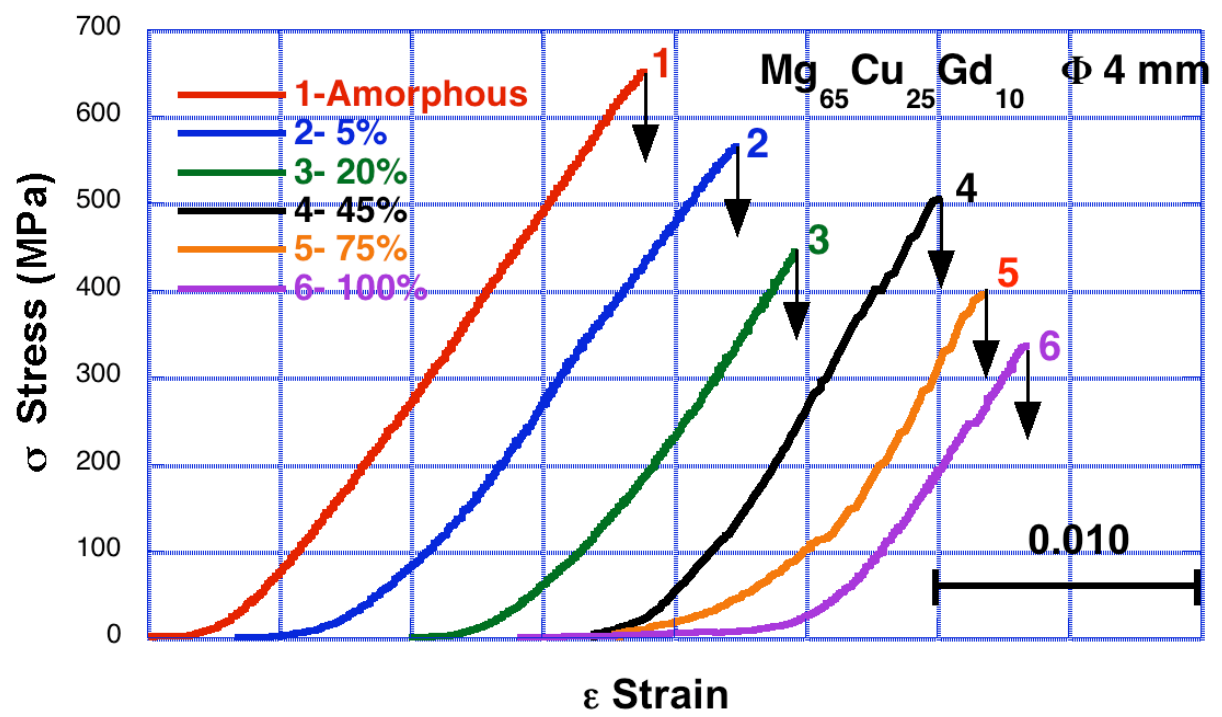

figure 4 


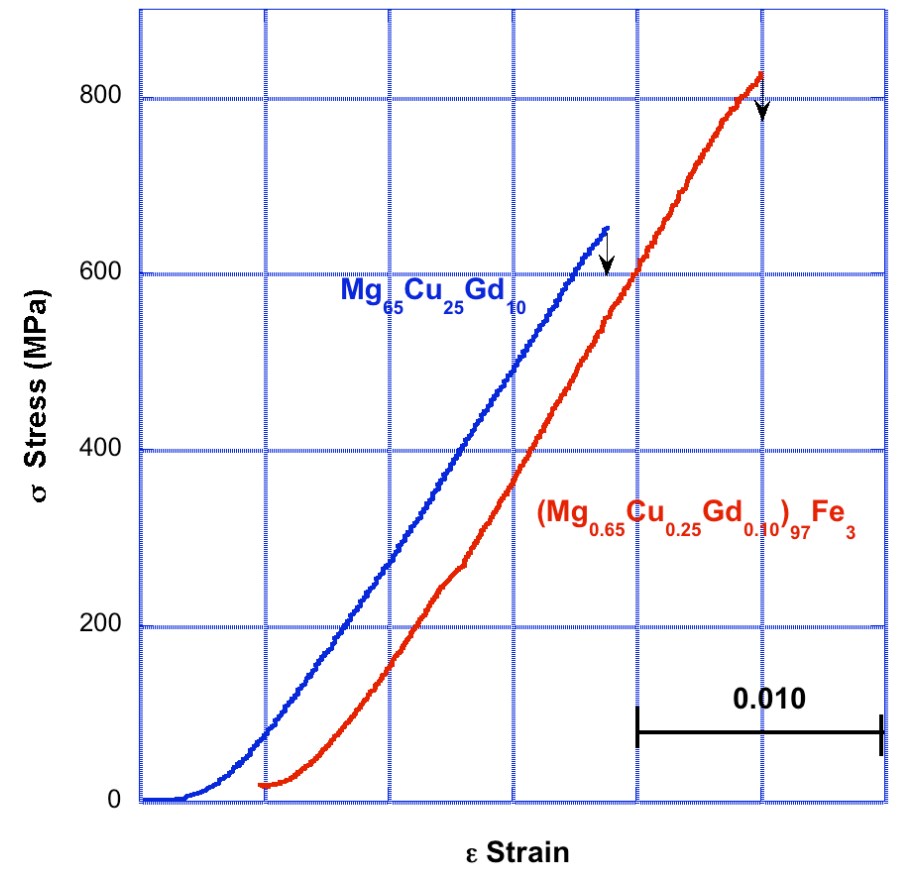

figure 5 


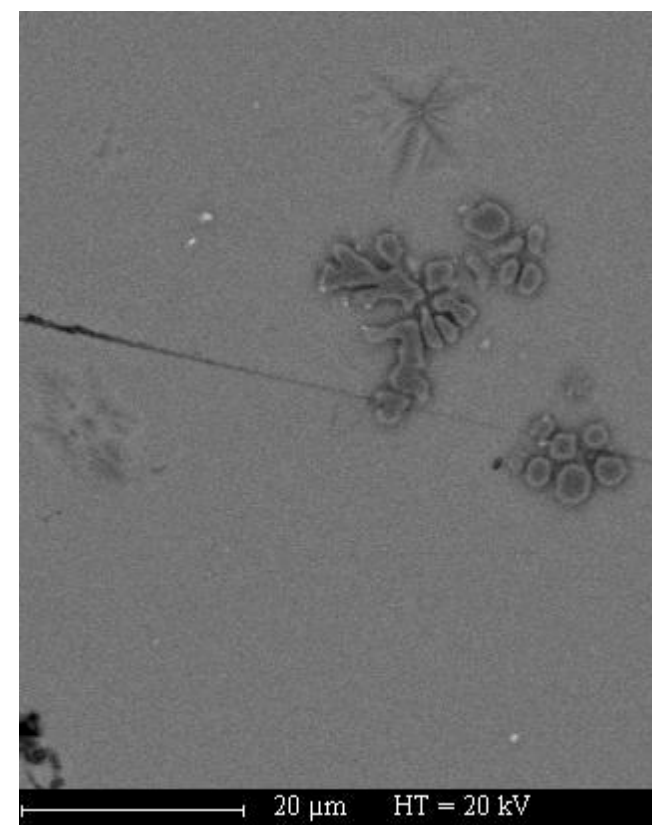

figure 6 


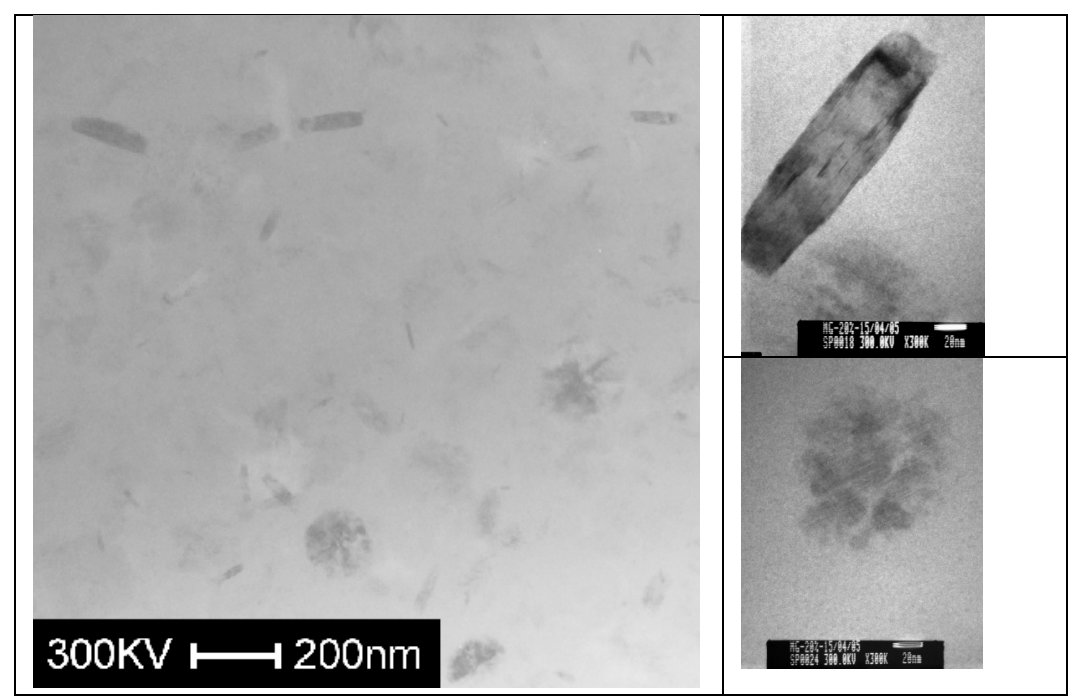

Figure 7 